\title{
REPRESENTATION OF AN UNRECOGNISED STATE UNDER INTERNATIONAL LAW - EXAMPLE OF THE REPUBLIC OF ARTSAKH
}

\begin{abstract}
Since the late 80s, the Armenian inhabitants of NagornoKarabakh, a region situated within the internationally recognised borders of the Republic of Azerbaijan, have been struggling for creating their own state - the Republic of Artsakh. The fact that this self-proclaimed entity was not recognised by any of the international actors has not prevented it from constantly committing to intervene on the international plane, separately from Yerevan and Baku. For instance, it is the co-signatory of the Bishkek Protocol. On the other hand, it was refused participation in the core undertaking of the international community designed to settle the dispute - the OSCE Minsk process.

The aforementioned situation raises the question as to who shall act as a legal representative of this quasi-state on the international plane? Azerbaijan, as the official centre of authority within the region, Armenia, or rather the separatist government of Nagorno-Karabakh?
\end{abstract}

Keywords: Nagorno-Karabakh Republic, Armenia, Azerbaijan, legal representatives

* Ph.D. Candidate at the Department of International and European Law, Faculty of Law, Administration and Economics, University of Wrocław, Poland 


\section{Introduction: right to represent a state in international relations}

For all subjects of international law, representation constitutes a crucial prerequisite of their presence on the international plane and, consequently, the capability to perform their rights (i.e. to conclude international agreements, to conduct diplomatic relations or to make claims under international law ${ }^{1}$ ). This representation is so tightly bound to a legal personality that, in some cases, it is hardly possible to indicate which of the two concepts is predominant. For instance, nations claiming their right to self-determination are granted the status of legal entity under international law only after having developed the basis of their statehood, compulsorily including organs capable of representing them in foreign affairs ${ }^{2}$. Without a duly appointed representative, any statement or action of the entity on the international plane would be rebuttable and would create a situation of legal uncertainty, as in the best case scenario, the binding force of its acts would depend on the good will of its international partners. Establishing who is capable to represent such an entity and on which grounds is thus one of the most significant problems when determining its legal status.

Legal norms regarding the issue of state representation in international relations may be found in both internal and international regulations. The former are shaped by the particularities of a regime operating in a given country and defines state organs entrusted with representation of a particular entity while managing its foreign affairs. For instance, article 8(1) of the Constitution of Azerbaijan stipulates that "[t]he President of the Republic of Azerbaijan [...] represents the Azerbaijanian state both within the country and in its relations with foreign countries"3. A similar, although more descriptive, solution may be found in article 55(7) of the Constitution of Armenia, which states that:

1 J. Barcik, T. Srogosz, Prawo międzynarodowe publiczne [International public law], C.H. Beck, Warszawa 2014, p. 143.

2 R. Bierzanek, J. Symonides, Prawo międzynarodowe publiczne [International public law], Lexis Nexis, Warszawa 2005, p. 119.

3 The Constitution of the Republic of Azerbaijan of 12.11.1995, available at: http:// en.president.az/azerbaijan/constitution, accessed: 20.01.2018. 
[t]he President of the Republic shall represent the Republic of Armenia in international relations, execute the general guidance of the foreign policy, conclude international agreements, forward the international agreements to the National Assembly for ratification and sign their ratification forms, approve, suspend or annul the international agreements for which no ratification is required ${ }^{4}$.

In comparison to internal laws, international legal regulation reveals a certain particularism. This refers to specific areas of international cooperation rather than to the issue of representation in general. This is illustrated by such examples as: the Vienna Convention on Diplomatic Relations of 1961, the Vienna Convention on Consular Relations of 1963, the Vienna Convention on the Law of Treaties of 1969 (article 7) or the Vienna Convention on the Representation of States in Relations with Universal International Organizations of 1975. Therefore, although certain solutions such as representation of state by the chief of its executive or the ambassador may be perceived as universally adopted, there exist questions that remain without a clearly articulated answer. For instance, are the above-mentioned organs capable of making binding declarations on behalf of the separatist regions or non-recognised states proclaimed within the territory of the state they represent?

\section{Implications of the Karabakh conflict for international representation of the region}

The current dispute over Nagorno-Karabakh is rooted at the events that took place at the turn of the 1980s and 1990s, when the Armenian inhabitants of the Nagorno-Karabakh, a region which at the time constituted an autonomous, but integral, part of the Azeri Republic, proclaimed its independence from Baku. The scheme of the described situation fits into a general pattern also reproduced by other territorial conflicts concerning the former Soviet Union, characterised by the participation of three main forces, which can be described as: an ethnic or national minority (in the discussed conflict: Armenians from Nagorno-Karabakh),

4 The Constitution of the Republic of Armenia of 5.07.1995 (as amended on 6.12.2015), available at: http://www.parliament.am/parliament.php?id=constitution\&lang=eng, accessed: 22.01.2018. 
a nationalising state (Azerbaijan) and the external homeland (Armenia) ${ }^{5}$. The independence of the Republic of Artsakh was proclaimed on 2.09.1991 and was not recognised by any state, not even Armenia ${ }^{6}$. Due to the lack of recognition, Karabakh is, in principle, unable to effectively perform state functions under international law, and its international status may be summarised as a place "[...] that do not exist in international relations; [...] a state-like entity that is not part of the international system of sovereign states; consequently [it is] shrouded in mystery and subject to myths and simplifications"

In theory, the aforementioned seems to a priori exclude the effectivity of any actions of its indigenous representatives. Accordingly, from the formal point of view, it could be assumed that this region is represented by Baku on the basis of the presumption of exclusive jurisdiction exercised by the Republic of Azerbaijan within its internationally recognised borders. Such a standpoint would be supported by constitutional provisions of the latter, according to which "no one except authorised representatives elected by the people will have the right to represent the people, speak on behalf of people and to make statements on behalf of people" ${ }^{8}$. The notion of authorised representatives is further explained by art. 8 II of the same act, which states that:

[t]he President of the Republic of Azerbaijan represents the unity of the Azerbaijanian people and provides continuity of Azerbaijanian statehood. The President of the Republic of Azerbaijan is guarantor of the independence and territorial integrity of the Azerbaijanian

5 N. Konarzewska, Nacjonalizm elit politycznych w republikach Kaukazu Południowegoźródła, przejawy $i$ konsekwencje [Nationalism of the political elite in the republics of the Southern Caucasus - sources, manifestations and consequences], [in:] T. Bodio (ed.), "Kaukaz: transformacja przywództwa i elit politycznych" ["Caucasus: transformation of leadership and political elites”], Oficyna Wydawnicza ASPRA-JR, Warszawa 2012, p. 165, pp. 311-342.

$6 \quad$ A. Balayan, Polityczne transformacje w postradzieckiej Armenii: problemy adaptacji i perspektywy integracji ze współczesnym światem [Political transformations in post-Soviet Armenia: problems of adaptation and prospects of integration with the modern world], [in:] R. Czachor (ed.), “Armenia i Górski Karabach w procesach transformacji społecznej i politycznej" ["Armenia and Nagorno-Karabakh in the processes of social and political transformation"], Fundacja Instytut Polsko - Rosyjski, Wrocław 2014, p. 30, pp. 25-50.

7 N. Caspersen, Unrecognized States. The Struggle for Sovereignty in the Modern International System, Polity Press, Cambridge 2012, p. 7.

8 Art. 2 of the Constitution of the Republic of Azerbaijan of 12.11.1995, available at: http://en.president.az/azerbaijan/constitution, accessed: 20.01.2018. 
state, observance of international agreements wherein the Republic of Azerbaijan is one of the parties ${ }^{9}$.

The spirit of the quoted provisions does not leave any space for doubts as to who shall be the only representative of the region of NagornoKarabakh and seems to be a firm answer to the events that took place within the Karabakh territory region at the beginning of the 90s before the Azeri Constitution was enacted. Nevertheless, presumption of representation of Artsakh by Baku, as if it was an usual administrative unit within Azerbaijan, would be a simplification, inadequate to encompass the complexity of the issue at stake, since one cannot ignore the fact that from the outset of the 90s, the latter is actually unable to exercise effective control over the disputed region. Therefore, if Baku is incapable of performing its prerogatives in Nagorno-Karabakh, especially to apply state coercion, then, ad maiori ad minus, from a very pragmatic perspective, it is rather unthinkable that Azerbaijan would be able to exercise the other state competences that do not involve the use of any sort of constraint. Moreover, the interests of Artsakh and Azerbaijan seem not to be convergent at all. Consequently, it appears that although legally entitled, Baku is not in a position to act as an effective representative of the Nagorno-Karabakh region.

Conversely, the state that is perceived to be in a position to actually represent the Karabakh interest, although not from the legal standpoint but rather from the perspective of compatibility of goals and the consent of Artsakh for mutual co-operation, is the neighbouring Armenia. Yerevan, for over two decades, is regarded as an advocate for Nagorno-Karabakh issue on the international plane ${ }^{10}$. According to Armenians, legal grounds for such a state of affairs may be found in the second section of art. 11 of the Armenian Constitution, which stipulates that:

[w] ithin the framework of the principles and norms of international law, the Republic of Armenia shall contribute to fostering relations

9 Ibidem, art. 8 III.

10 For instance, representatives of Karabakh were refused participation in peace talks organised under the auspices of the Conference of Security and Co-operation in Europe. Therefore, during the 1990s, the Armenian government repeatedly underlined that they would accept any peace solution elaborated upon by CSCE, subject to its acceptation by Armenians from Karabakh. (P. Adamczewski, Górski Karabach w polityce niepodległego Azerbejdżanu [Nagorno-Karabakh in the politics of an independent Azerbaijan], Dialog, Warszawa 2012, p. 263). 
with the Armenian Diaspora, protecting the Armenian historical and cultural values located in other countries, advancing Armenian education and culture.

This provision, despite its rather programmatic character, is, however, extremely often and broadly used in practice. In the context of fostering the interests of Armenians on the international arena, two examples of its implementation on a daily basis are especially noteworthy - the Armenian diaspora itself and the Hayastan All-Armenian Fund. Both of them, despite the fact that they are not public entities under Armenian law, seem to be, in fact, governmental agendas acting on behalf of Yerevan in some more sensitive circumstances.

Undoubtedly the Armenian inhabitants of Azerbaijan fall within the scope of the legal definition of diaspora contained in section 1(1) of the Charter of the Ministry of Diaspora of the Republic of Armenia enacted on $24.09 .2008^{11}$, which defines the term as "all Armenian cultural, charitable, compatriotic, youth, educational, scientific, trade, ideological organisations and committees, different religious congregations, institutions, structures, unions, foundations or associations, mass media and other bodies, individuals" ${ }^{12}$. In fact, it seems to constitute a tool for fostering Karabakh interests on the international plane and a means through which the unrecognised Republic of Artsakh runs its international policy $^{13}$. For instance, in 1992, the US Congress adopted the Freedom Support Act aimed at promotion of political and economic changes in newly independent states ${ }^{14}$. Under pressure from the Armenian lobby, amendment 907, which barred United States assistance to the Government of Azerbaijan

11 Appendix number 1 to Resolution number 1049-N of the Government of the Republic of Armenia of 11.09.2008.

12 The Charter of the Ministry of Diaspora of the Republic of Armenia enacted on 24.09.2008 (being Appendix number 1 to Resolution number 1049-N of the Government of the Republic of Armenia of 11.09.2008), http://www.mindiaspora.am/en/Gov_ desicions, accessed: 26.01.2018.

13 S. Markedonov, Republika Górskiego Karabachu: kształtowanie się niepodległego państwa [Republic of Nagorno-Karabakh: the formation of an independent state], [in:] R. Czachor (ed.), "Armenia i Górski Karabach w procesach transformacji społecznej i politycznej" ["Armenia and Nagorno-Karabakh in the processes of social and political transformation"], Wydawnictwo Instytut Polsko - Rosyjski, Wrocław 2014, p. 131, pp. 128-152.

14 T. de Waal, Black Garden. Armenia and Azerbaijan through Peace and War, New York University Press, New York 2003, p. 234. 
"until the President determines, and so reports to the Congress, that the Government of Azerbaijan is taking demonstrable steps to cease all blockades and other offensive uses of force against Armenia and NagornoKarabakh"15, was adopted. What is more, it is said that it is thanks to the diaspora that unlike representatives of Abkhasia, Ossetia or Transnistria, the authorities of Karabakh could travel to Western Europe and the United States (in 1993 R. Kocharyan, 'prime minister' of Karabakh at the time, visited France and Belgium, and appeared at the International NATO Academy $\left.{ }^{16}\right)^{17}$. Despite the fact that the activity of the Armenian diaspora shall be rather perceived as a private undertaking or public diplomacy ${ }^{18}$, its example clearly indicates its impact on relations between Armenia, Karabakh and the West.

The Fund was established by Armenian presidential decree on 3.03.1992, with a view to overcome economic problems associated with the break-up of the Soviet Union, the 1988 Spitak earthquake, an economic blockade and to support the rehabilitation of areas that had suffered from the Artsakh conflict ${ }^{19}$. It is currently described as "the largest humanitarian organisation serving the needs of the Republic of Armenia and the Artsakh Republic, with the mission to connect the people of Armenia with the worldwide Armenian diaspora to create a better homeland for the Armenian nation" ${ }^{20}$. It is widely believed (which was also reflected in the decision of the European Court of Human Rights in the case of Chiragov and others v. Armenia) to be sort of state organ of Armenia:

15 US Freedom Support Act of 24.10.1992, available at: https://www.congress.gov/ bill/102nd-congress/senate-bill/2532/text, accessed: 25.01.2018.

16 S. Markedonov, op. cit., p. 142.

17 P. Adamczewski, Górski Karabach w polityce niepodległego Azerbejdżanu [NagornoKarabakh in the policy of an independent Azerbaijan], Dialog, Warszawa 2012, p. 290.

18 There is no single agreed-upon definition of the term; the Center for Public Diplomacy defines it as "the public, interactive dimension of diplomacy which is not only global in nature, but also involves a multitude of actors and networks. It is a key mechanism through which nations foster mutual trust and productive relationships and has become crucial to building a secure global environment". (Official Website of University of South California Center for Public Diplomacy, https://uscpublicdiplomacy. org/page/what-pd, accessed: 25.01.2018).

19 Chiragov and Others v. Armenia, Application no. 13216/05, Judgment of 16.06.2015, ECHR 2015, para. 26.

20 Official website of Hayastan All-Armenian Fund https://www.armeniafund.org/ about/, accessed: 23.01.2018. 
[w] hile the fund is not a governmental institution and its resources come from individual donations, it is noteworthy that [...] the Armenian president is the ex officio president of the Board of Trustees, and the board includes among its members several present and former presidents and ministers of Armenia and the "NKR" [NagornoKarabakh Republic], as well as other prominent officials of Armenia. While these members do not make up a majority, it is clear from the board's composition that the official representatives of Armenia together with their "NKR" counterparts - are in a position to greatly influence the fund's activities ${ }^{21}$.

Although neither the Diaspora nor Fund can be described as official representatives of the Republic of Armenia, their close cooperation with central authorities in Yerevan, as well as a long-standing practice of activity in foreign relations, especially within the field of fostering Karabakh interests, seem to make their actions imputable to Armenia. Nevertheless, there exist some obstacles for perceiving Yerevan as an official representative of Nagorno-Karabakh in international relations. First of all, it should be underlined that from a formal point of view, any attempt to officially represent the unrecognised Republic of Artsakh by Yerevan constitutes a violation of the fundamental principles of international law by interfering in the internal affairs of a third country, namely Azerbaijan. Although this allegation is already extremely common in the context of financial or military support provided by Armenia to Karabakh, it seems that an official representation on the international arena would confirm its regularity. Furthermore, the establishment of an Armenian representation of the Nagorno-Karabakh region on the international plane does not really provide an unequivocal answer as to demarcation between the actual scope of activity of Yerevan and Stepanakert. Moreover, historical events demonstrate that Armenia does not always necessarily embrace the developments in the Artsakh Republic. For instance, while commenting on the events of 20.02.1988, when the decision on seceding from Azerbaijan was made, a former high-ranking Armenian official, G. Voskanian, said that:

the leadership in Yerevan had been warned to expect a campaign in Stepanakert, but were unable to keep pace with developments: "We knew that this question existed, but we had agreed with [the Party leadership in Stepanakert] that they would let us know in advance 
when they passed their resolution about leaving Azerbaijan. But, as it turned out, they caught us by surprise when they passed the resolution"22.

Therefore, if neither Armenia nor Azerbaijan are able to effectively and legally represent Karabakh, the question as to whether the separatist authorities themselves may represent the Republic of Artsakh should be addressed.

\section{Karabakh authorities as representatives of the Republic of Artsakh: legal framework}

While analysing the possible scenario of the independent, though limited to some particular cases, occurrence of Nagorno-Karabakh in international relations, the first question to be raised is whether such situations are admissible in international practice, and secondly, whether are they allowed by international law.

Obviously, it would be a truism to say that the practice is subjected to political relations between interested parties. Nevertheless, despite the significant level of politicisation of the discussed problem, this case is also being analysed by lawyers, which is primarily reflected in the solutions proposed by national courts in relation to the cases of the recognition of acts issued by the authorities of the unrecognised state. Here, the national jurisprudence of many states is eager to admit that the private interests of the citizens of these self-proclaimed entities, and even the entity itself, may be, to a greater or lesser extent, protected by international law ${ }^{23}$. Some arguments in favour of the international activity of unrecognised states may also be sought in international practice regarding the conclusion of agreements between states and non-state actors, mostly unrecognised governments, and participation of the latter in international organisations. For instance, the United States, while refusing for many years to recognise the Soviet Government, was nonetheless a co-signatory to the Sanitary Convention, underlining that this had not implied the recognition

22 T. de Waal, op. cit., p. 25.

23 R. Bierzanek, La non-reconnaissance et le droit international contemporain [Nonrecognition and contemporary international law], "Annuaire français de droit international" 1962, vol. 8, p. 117, p. 125. 
of the latter ${ }^{24}$. Nowadays, Taiwan is, independently from the People's Republic of China, a member of e.g. WTO, the International Olympic Committee and the Asia-Pacific Economic Cooperation ${ }^{25}$.

Furthermore, another example may be the Stabilisation and Association Agreement of 2015, concluded between the European Union and the European Atomic Energy Community and Kosovo. Since the decision on whether to recognise an entity or not remines entirely within the sphere of competences of Member States, Kosovo has been recognised only by 23 out of 28 of states. Not to disturb this fragile balance, the Agreement contains a disclaimer, according to which:

[n] one of the terms, wording or definitions used in this Agreement, including the Annexes and Protocols thereto, constitute recognition of Kosovo by the EU as an independent State, nor does it constitute recognition by individual Member States of Kosovo in that capacity where they have not taken such a step ${ }^{26}$.

Analysing the aforementioned examples, it is impossible not to agree with prof. Bierzanek, who indicates that:

[...] non-recognition does not preclude that the mutual relations between the non-recognising State and the unrecognised State are being subject to the rules of international law, as well as that the unrecognised State has rights and duties as if it was a subject of international law ${ }^{27}$.

With regard to the aforementioned, one should affirmatively answer the question about the admissibility, at least to a certain extent, of unrecognised entities to act independently on the international plane.

Providing this kind of response entails the necessity to put it within a legal framework and to define on which legal basis these entities can participate in international co-operation. It seems that two grounds for this state of affairs may be taken into account. First of all, the principle

24 Ibidem, p. 126.

25 C.E. Hickson, Taiwan In International Organizations: Internationalization of the Taiwan-China Relationship, bm 2003, p.1, accessed: 23.04.2018. https://www.files. ethz.ch/isn/44789/2003_05_Taiwan_in_International_Organizations.pdf.

26 Art. 2 of the Stabilisation and Association agreement between the European Union and the European Atomic Energy Community, of the one part, and Kosovo, of the other part, adopted on 27.10.2015.

27 R. Bierzanek, op. cit., p. 128. 
of respect for human rights, which should eventually supersede the issues related to political divisions. It finds, however, its application in relations between individuals (rather than unrecognised states) and sovereign states. For instance, according to the advisory opinion of the ICJ:

while official acts performed by the Government of South Africa on behalf of or concerning Namibia after the termination of the mandate were illegal and invalid, this invalidity could not be extended to those acts such as, for instance, the registration of births, deaths or marriages, the effects of which could be ignored only to the detriment of the inhabitants of that territory ${ }^{28}$.

Furthermore, such an approach is also adopted by the European Courts of Human Rights. In Cyprus v. Turkey, the case regarding the problem of the unrecognised Turkish Republic of Northern Cyprus (TRNC), the Court held that:

[...] the obligation to disregard acts of de facto entities is far from absolute. Life goes on in the territory concerned for its inhabitants. That life must be made tolerable and be protected by the de facto authorities, including their courts; and, in the very interest of the inhabitants, the acts of these authorities related thereto cannot be simply ignored by third States or by international institutions [...]. To hold otherwise would amount to stripping the inhabitants of the territory of all their rights whenever they are discussed in an international context, which would amount to depriving them even of the minimum standard of rights to which they are entitled ${ }^{29}$.

Nevertheless, although those conclusions may seem full of promise, one should not ignore the fact that from the perspective of non-state entities, such a construction is incomplete. Eventually, responsibility for the breach of Convention is attributed to its State Parties and not to the selfproclaimed governments that, by definition, are incapable of becoming its signatories $^{30}$. Furthermore, although protection of human rights is vital, it constitutes just a piece of the activity of international actors.

28 Legal Consequences for States of the Continued Presence of South Africa in Namibia (South West Africa), notwithstanding Security Council Resolution 276 (1970), Merits, ICJ Advisory Opinion of 21.06.1971, I.C.J. Reports 1971, p. 16, para. 125.

${ }^{29}$ Cyprusv. Turkey, Application no. 25781/94, judgment of 23.03.1995, ECHR1995, para. 96,

30 See: e.g. Chiragov and Others v. Armenia, Application no. 13216/05, Judgment of 16.06.2015, ECHR 2015; Sargsyan v. Azerbaijan, Application no. 40167/06, Judgment of 16.06.2015, ECHR 2015. 
On the other hand, the cases of unrecognised states bring to mind the legal status of national liberation movements, insurgents or belligerents - temporary subjects of international law, which constitute an intermediate stage in pursuit of a full legal international personality in the form of recognition as a state. They acquire their limited personality under international law after having been recognised as such by states or international organisations ${ }^{31}$. According to the ICJ:

these collective non-state actors are a special case of legal person and at least have sufficient personality for certain agreements. For example, Article 3 of the Vienna Convention on the Law of Treaties (VCLT) did not exclude the treaty-making capacity for non-state entities and, by doing so, perhaps, implicitly confirmed it ${ }^{32}$.

For instance, the ICJ appears to consider the Oslo Accords of 1993 between Israel and Palestine (concluded between the government of the former and by the Palestine Liberation Organisation, PLO, on behalf of the latter) to be a binding act of international law ${ }^{33}$. Nonetheless, the PLO seems to be a very particular entity of international law, with an unusually developed status, making its factual and legal position closer to a state entity and, therefore, hardly comparable to that of Armenians from Nagorno-Karabakh.

The other concept that should be taken into account is that of insurgents or belligerents. Nevertheless, the international legal doctrine doubts the exact character of the acts they conclude, describing them as a reaffirmation rather than constitution of the existing rights and obligations ${ }^{34}$. What also needs to be stressed is the fact that the Armenian population of Nagorno-Karabakh has never been recognised as either of the aforementioned.

Taking all of the aforementioned into consideration, it seems that currently there is no legal framework for international representation of unrecognised states. Nevertheless, a sort of side gate may be seen in the concept of effectivity. As professor B. Mielnik underlines, in every case wanting to confirm the existence of a person of international law, subjecting

31 W. Czapliński, A. Wyrozumska, Prawo międzynarodowe publiczne. Zagadnienia systemowe [Public International Law. System Issues], C.H. Beck, Warszawa 2014, p. 606.

32 W. T. Worster, Relative International Legal Personality of Non State Actors, "Brooklyn Journal of International Law" 2016, vol. 42, no. 1, p. 207, p. 226.

33 Ibidem, p. 222-223.

34 Ibidem, p. 234. 
it to analysis in terms of effectivity may allow one to indicate the actual position of a person in the sphere of international relations and the scope of its rights ${ }^{35}$. But what does it actually mean for an entity to be effective? Paradoxically, the perception of effectivity seems to oscillate around the issue of representation. For instance, when it comes to a nation claiming its right to self-determination, the activity of the group on the international plane, its status under national law and whether the nation disposes any group of real representatives capable of representing it on the international plane are the paramount criteria to be analysed ${ }^{36}$. The latter is established while examining the manner of appointment of the representatives; that is to say: verifying whether they were elected by the nation itself or if rather they were imposed by third parties ${ }^{37}$. A nation that during a struggle for national liberation creates the foundations of its statehood and organises civilian or military organs capable of representing it on an international level has a chance to become a subject of international law and, consequently, is treated as a kind of state in statu nascendi ${ }^{38}$.

\section{Activity of Karabakh representatives on the international plane: the issue of effectivity}

Bearing in mind that effectivity cannot be analysed in abstracto, one should have a closer look at the actual activity of the representatives of the Republic of Artsakh on the international plane. At first, this issue may be examined from the perspectives of its two Constitutions: the former adopted on 10.12.2006 and the latter on 10.02.2017. Both of them characterise the President as the representative of Artsakh in international relations, stipulating that he "[...] conducts and oversees the general course of the foreign policy, signs international treaties, presents international agreements to the National Assembly for ratification,

35 B. Mielnik, Podmiotowość a efektywność [Subjectivityversus effectivity], [in:] B. Mielnik, A. Wnukiewicz - Kozłowska (eds.), "Podmiotowość w prawie międzynarodowym" ["Subjectivity in international law"], Wydawnictwo Uniwersytetu Wrocławskiego, Wrocław 2013, pp. 65-66, pp. 64-83.

36 Ibidem, p. 76-77.

37 Ibidem, p. 77.

38 R. Bierzanek, J. Symonides, op. cit., note 2, p. 135. 
confirms, suspends or halts the ratification of international agreements not requiring ratification" ${ }^{39}$.

The history of activity of representatives of Nagorno-Karabakh on the international plane is, however, much longer. On 26.08.1919, the Provisional Accord was concluded between the Armenians of Karabakh and the Government of Azerbaijan, which implied submission to Baku's rule ${ }^{40}$. Although the context seems to demonstrate that Azeri authorities should have considered the people acting on behalf of Karabakh to be its official and effective representatives (since otherwise they would not claim the validity of the agreement they made), Armenian doctrine is rather doubtful about this. To overcome the disadvantageous consequences of the act, it underlines that:

the Accord of August 1919 was signed by representatives of the Seventh Assembly of Karabakh, not the representatives of the Republic of Armenia ${ }^{41}$. Therefore, the Accord was not a 'treaty' under international law, because Karabakh, which was not a state at the time, did not have standing to enter into an international agreement ${ }^{42}$.

Although the position of Karabakh in foreign discourse diminished afterwards, and until the 1990s, it was not a party to any other treaty, M. Gorbachev noticed the need to involve Karabakh representatives into discussion. In the 1980s, the Artsakh case was an internal conflict within the Soviet Union, and the region itself had the status of mere autonomy within Azerbaijan, the leader decided to send two delegations of peace negotiators to the Caucasus - one to Azerbaijan and the second to Nagorno$\mathrm{Karabakh}^{43}$. Later, an urgent need for Stepanakert involvement, separately from Yerevan, was also seen by Azerbaijani President H. Aliyev, who on

39 Cf.: article 68(11) of the Constitution of 2006, article 93(8) of the Constitution of 2017.

40 T. Musajew, Kosowo a roszczenia Armenii wobec regionu Górskiego Karabachu Azerbejdżanu. Porównawcza analiza prawna [Kosovo and Armenia's claims against the NagornoKarabakh region of Azerbaijan. Comparative legal analysis], Oficyna Olsztyńska, Warszawa 2013, p. 21.

41 A. Tamzarian, Nagorno-Karabagh's Right to Political Independence Under International Law: an Application of the Principle of Self-Determination, "Southwestern University Law Review" 1994, vol. 24 p. 183, p. 206-207.

${ }^{42}$ Ibidem, p. 207.

43 T. de Waal, op. cit. note 16, p. 13. 
1.09.1993 declared that he was ready to talk to Armenians from Karabakh. This affirmation, in fact, constituted a breakthrough that has not yet been surpassed, since no Azeri politician had even dared to consider a proposal to negotiate with the separatists directly, fearing that this gesture would be perceived as indirect recognition ${ }^{44}$ (so far, the partner in talks with Baku was always Yerevan ${ }^{45}$ ). In fact, the talks started on 9.09.1993 Azerbaijan was represented by its Parliament's Chief deputy, A. Dzhalilov, while A. Ghukasyan, the 'minister of foreign affairs' of the Nagorno-Karabakh Republic, was acting on behalf of this unrecognised entity ${ }^{46}$.

Moreover, the Karabakh representatives, alongside representatives of Yerevan and Baku, were official co-signatories of the Bishkek Protocol of 5.05.1994 - the ceasefire agreement being actually the only binding conclusion that has been reached so far ${ }^{47}$. During negotiations, delegations from Azerbaijan, Armenia and Karabakh were composed of members of their respective parliaments ${ }^{48}$. The Protocol was elaborated upon through the active participation of the Community of Independent States acting as a facilitator. Interestingly, the presidents of the two leading states of the latter, Russia and Kazakhstan, started peace talks that involved Baku, Yerevan and Stepanakert much earlier - in September $1991^{49}$.

Despite the above-mentioned clear examples of recognition of Karabakh Armenians at least as a party to the dispute, the Azerbaijani approach towards Stepanakert is highly preservative, usually explained by fearing that any further interaction may be perceived as a tacit recognition of the Republic of Artsakh. Baku has repeatedly denied participation of the representatives of Artsakh in peace talks lead by the OSCE Minsk Group. Although the CSCE, the predecessor of the latter, wanted all interested parties to take part in the negotiations, including Nagorno-Karabakh ${ }^{50}$, Azerbaijanis opposed this, claiming at first that the Karabakh conflict was Armenian aggression ${ }^{51}$ and constituted a dispute between Azerbaijan and

44 P. Kwiatkiewicz, Azerbejdżan: ukształtowanie niepodległego państwa [Azerbaijan: formation of an independent state], Wydawnictwo Adam Marszałek, Toruń 2009, p. 306.

45 Ibidem, p. 307.

46 Ibidem, p. 315.

47 Bishkek Protocol of 5.05.1994, text available at: http://www.usazeris.org/ ArmeniaAzerbaijanCeasefireAgreementBishkekProtocol1994.pdf, accessed: 27.01.2018.

48 P. Adamczewski, op. cit, p. 295.

49 Ibidem, p. 291.

50 Ibidem, p. 263.

51 Ibidem, p. 270. 
Armenia exclusively ${ }^{52}$. It further explained that the Karabakh Armenians were a national minority and consequently, in contrast to the nation, did not enjoy the right to self-determination under international law ${ }^{53}$. Nevertheless, Baku was eager to agree upon the participation of Karabakhi representatives subject to admission of Azerbaijani refugees from NagornoKarabakh to the talks, too. The proposition failed due to Armenian refusal, motivated by the fear of a reduction of the rank of the representatives of Karabakh ${ }^{54}$. As a result, they were forced into the role of informal participation in the works as a group that does not really represent anyone. It was believed that if the conclusion could be agreed upon, the representatives of Stepanakert would become the official delegation and would validate the undertaken decisions. This solution, adopted in the 1990s, has been applied ever since ${ }^{55}$, with the exception of the practice implied in the period between 1993 and 1997, according to which all three parties were mentioned in the official documents of the Group ${ }^{56}$.

It is also noteworthy that an approach according to which a distinction shall be made between Armenia and Karabakh Armenians was also adopted by the UN Security Council which in its resolution 853 of 29.07.1993, which urged:

[...] the Government of the Republic of Armenia to continue to exert its influence to achieve compliance by the Armenians of the NagornoKarabakh region of the Azerbaijani Republic with its resolution 822 (1993) and the present resolution, and the acceptance by this party of the proposals of the Minsk Group of the CSCE $[\ldots]^{57}$.

52 P. Adamczewski, Przywództwo na poradzieckim obszarze o nieustalonym statusie. Casus Górskiego Karabachu [Leadership in the post-Soviet territory of unidentified status. Casus of Nagorno-Karabakh], [in:] T. Bodio (ed.), "Kaukaz: mechanizmy legitymizacji i funkcjonowania elit politycznych" ["Caucasus: mechanisms of legitimacy and functioning of political elites”], Oficyna Wydawnicza ASPRA, Warszawa: 2012, pp. 187188, pp. 163-192.

${ }_{53}$ N. Konarzewska, op. cit., p. 182.

54 P. Adamczewski, op. cit., p. 187.

55 Ibidem p. 264

56 Ibidem, p. 290

57 United Nations Security Council Resolution 853 (1993), adopted by the Security Council at its 3259 meeting, on 29.07.1993 


\section{Conclusion}

Although both national and international law deal with the issue of representation of an entity on the international plane, these regulations are insufficient to address the problem of representation of unrecognised states. On the one hand, internal law is not always up to date with developments within a state (e.g. Azeri Constitution), or it adopts solutions that may be disputable from the standpoint of the general norms of international law (e.g. Armenian Constitution). When it comes to international law, it does not regulate this particular issue at all. The answer is, therefore, to be sought in international practice. The latter is highly partitioned and inconsistent. Although, historically and currently, one may find some cases where it seems to admit the binding character of acts of representatives of unrecognised states, one shall not perceive this as a general rule, but rather as a very casuistic and uncertain practice. Usually, such a positive approach is justified by human rights protection and certainty of the legal status of individuals. Moreover, in any event, entering into contractual relations with self-proclaimed republics implies their tacit recognition.

When it comes to the issue of the Republic of Artsakh itself, the legal status of its representatives seems to be over-regulated on national levels, under-regulated by international law and complicated even more by international practice. The first group offers solutions justifying representation of Nagorno-Karabakh by all three disputing parties: Baku, Yerevan and even Stepanakert. None of these propositions seem to be satisfying - the first of them, while being the only legitimated from perspective of international law, is not effective at all. The second, although much closer to fulfilling the criterion of reality, is doubtful in terms of legality, as the international community perceives Armenia as an aggressor in the conflict, while the third option seems to be neither legitimate nor effective.

Moreover, on the one hand, international organisations such as the UN, OSCE or CIS seem to identify Karabakh representatives as a necessary component of the peace process. Yerevan adopts the position in line with aforementioned - from the very beginning of the conflict, it advocates for the involvement of Karabakh Armenians in the international dialogue. On the other hand, Baku, for over 15 years, has refused their official representation to take part in negotiations, despite the fact that from the historical point of view, it had admitted their presence and, what is more, the binding force of their declarations. Therefore, the issue 
of the adequate representation of the Republic of Artsakh in the peace process is one of its most neuralgic aspects, as well as the one that precludes parties to the dispute from elaborating upon an adequate solution to their over 25 year dispute. It seems that in order to reach a conclusion that would be acceptable for all conflicted parties, this problem not only should be addressed, but should also be resolved by a positive approach towards the presence of indigenous representatives of the Republic of Artsakh, making it possible for them to present their interests independently but without the necessity to recognise them as any of the subjects of international law.

\section{Bibliography}

1. Adamczewski P., Górski Karabach w polityce niepodległego Azerbejdżanu, Dialog, Warszawa 2012

2. Adamczewski P, Przywództwo na poradzieckim obszarze o nieustalonym statusie. Casus Górskiego Karabachu, [in:] T. Bodio (ed.), "Kaukaz: mechanizmy legitymizacji i funkcjonowania elit politycznych", Oficyna Wydawnicza ASPRA-JR, Warszawa 2012

3. Balayan A., Polityczne transformacje w postradzieckiej Armenii: problemy adaptacji i perspektywy integracji ze wspótczesnym światem, [in:] R. Czachor (ed.), "Armenia i Górski Karabach w procesach transformacji społecznej i politycznej", Fundacja Instytut Polsko - Rosyjski, Wrocław 2014

4. $\quad$ Barcik J., Srogosz T., Prawo międzynarodowe publiczne [International public law], C.H. Beck, Warszawa 2014

5. Bierzanek R., La non-reconnaissance et le droit international contemporain: "Annuaire français de droit international" 1962, vol. 8

6. Bierzanek R., Symonides J., Prawo międzynarodowe publiczne, Lexis Nexis, Warszawa 2005

7. Caspersen N., Unrecognized States. The Struggle for Sovereignty in the Modern International System, Polity Press, Cambridge 2012

8. Czapliński W., Wyrozumska A., Prawo międzynarodowe publiczne. Zagadnienia systemowe, C.H. Beck, Warszawa 2014

9. De Waal T., Black Garden. Armenia and Azerbaijan through Peace and War, New York University Press, New York 2003

10. Hickson C.E., Taiwan In International Organizations: Internationalization of the Taiwan-China Relationship, 2003, p. 1, access: 23.04 .2018 https:// www.files.ethz.ch/isn/44789/2003_05_Taiwan_in_International_ Organizations.pdf 
11. Konarzewska N., Nacjonalizm elit politycznych $w$ republikach Kaukazu Południowego - źródła, przejawy i konsekwencje, [in:] T. Bodio (ed.), "Kaukaz: transformacja przywództwa i elit politycznych", Oficyna Wydawnicza ASPRA-JR, Warszawa 2012

12. Kwiatkiewicz P., Azerbejdżan: ukształtowanie niepodległego państwa, Wydawnictwo Adam Marszałek, Toruń 2009

13. Markedonov S., Republika Górskiego Karabachu: kształtowanie sięniepodległego państwa, [in:] R. Czachor (ed.), "Armenia i Górski Karabach w procesach transformacji społecznej i politycznej", Fundacja Instytut Polsko - Rosyjski, Wrocław 2014

14. Mielnik B., Podmiotowość a efektywność, [in:] B. Mielnik, A. Wnukiewicz Kozłowska (eds.), "Podmiotowość w prawie międzynarodowym", Wydawnictwo Uniwersytetu Wrocławskiego, Wrocław 2013

15. Musajew T., Kosowo a roszczenia Armenii wobec regionu Górskiego Karabachu Azerbejdżanu. Porównawcza analiza prawna, Oficyna Olsztyńska, Warszawa 2013

16. Tamzarian A., Nagorno-Karabagh's Right to Political Independence Under International Law: an Application of the Principle of Self-Determination, "Southwestern University Law Review" 1994, vol. 24

17. Worster W. T., Relative International Legal Personality of Non State Actors, "Brooklyn Journal of International Law" 2016, vol. 42, no. 1 